\title{
New broom at the DHSS
}

EFFORTS to streamline the administration of medical research have been promised by the new chief scientist at the UK Department of Health and Social Security, Professor Arthur Buller.

The promise is likely to be widely welcomed by Britain's medical science community. There has been growing frustration in recent months at the burdens imposed on research by the implementation of Lord Rothschild's proposals for research council funding.

Professor Buller brings to the job a growing awareness that the Medical Research Council (MRC) and the DHSS must work closely together, and with mutual trust, if the new system is to be made to work. Only this, for example, will avoid the DHSS presenting the research council with requests -such as a "cure for schizophrenia" -that are impossible to meet at the present time.

A close liaison will also, Professor Buller fecls, avoid a repetition of the situation that arose two years ago when the Government's economic problems led to hastily imposed cutbacks of department rescarch budgets, and consequently a reduction of $\$ 900,000$ in the money available to the MRC from the DHSS.

"It is impossible to maintain any type of meaningful relationship between the two bodies if this type of thing, which happens when administration gets quite separated from research, is liable to take place. From the MRC's point of view, last time was a near disaster."

Professor Buller, whose appointment was announced last week, will takc up his new position with responsibility for a $£ 28 \mathrm{~m}$ research budget from the beginning of January. He is keen to reduce the cxtra administration that the Rothschild proposais have involved, a desire he shares with the new secretary of the Medical Research Council, Professor James Gowans.

Unlike many scientists, however, he does not criticise the philosophy behind the proposals, under which about $25^{\prime \prime}$, of the MRC's $\$ 52 \mathrm{~m}$ research budget is now allocated by the department to the research council on a "customer-contractor" basis.

According to Professor Buller, the problem lies in the way that this has been done. "In the past, too much of a meal has heen made of being seen to implement Rothschild. An enormous exercise, which has been expensive and timc-consuming for both scientists and administrators, has been mounted so that both sides could demonstrate that they were carrying out Rothschild's recommendations", he says.
By cutting down on this type of activity, while concentrating on what remains necessary to maintain an effective partnership between the MRC and the DHSS, Professor Buller hopes to simplify the administrative system between the two bodies, without any loss of effectiveness. And it is a goal which, he claims, is already shared by the DHSS.

Professor Buller has been seconded to the department from the University of Bristol, at which he is professor of physiology and dean of the faculty of medicine. He shares a general reputation claimed by the university for pragmatism rather than politics in administrative affairs, although membership of the non-academic staff salaries committee has made him no stranger to the latter.

Buller gained further experience in the world of medical politics at the MRC itself, where he is at present chairman of the neurobiology and mental health board and a council member. The board's main concern in recent years can, he says, be succinctly summarised: "We have spent our time trying to live with Rothschild".

One of Buller's aims likely to receive widcspread support among scientists is his desire to return the initiative on research back to the research worker. The most important thing, he stresses. in avoiding the waste of money is to get good scientists doing rescarch, and then

\section{Indian science reorganised}

THE Indian government has now issued a list of the 17 laboratories that it intends to detach from their present position with the Council of Scientific and Industrial Research (CSIR) and relocate within user ministries (10 November, page 89). They are: ten research associations (to Industry), three museums (to Education), the Indian Institute of Petroleum (to Petroleum and Chemicals), the Road Research Institute (to Transport and Shipping), the Central Fuel Research Institute (to Energy) and the Building Research Institute (to Welfare and Housing).

In contrast to the earlier fears that the government would dismember CSIR and shatter morale, first reactions seem to be relief that the transfer has only affected laboratories most easily housed in a ministry.

\section{Following a Maoist path}

Romanian science is being systematically ruined "on the Chinese model". according to Dr Mihai Dediu, a Romanian mathematician recently exiled with his family to Italy after his cam-

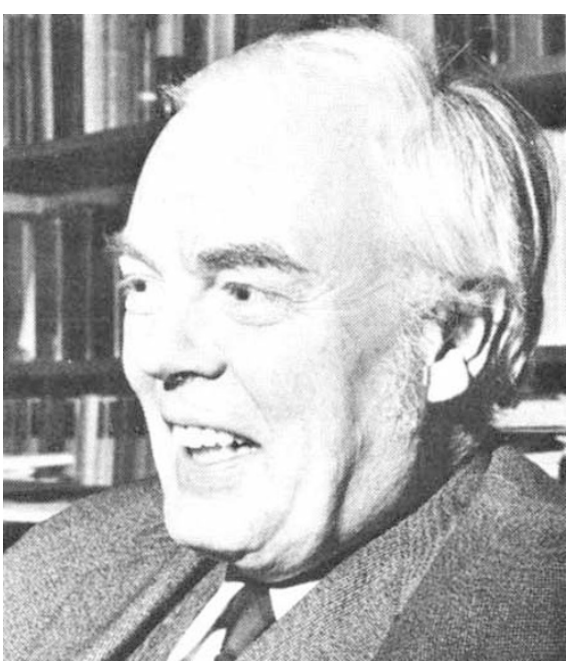

Arthur Buller, new chief scientist

to a certain extent to follow their judgements.

The real need is not the development of ways of directing research from outside, but the successful application of its findings. "We need to keep a very sharp eye on ways in which the research being done by scientists in ivory towers can be exploited for the improvement of health care", he says.

"In the past a number of important discoveries have lain fallow and not been exploited. Penicillin is an example where a failure to pick up the possibilities early enough meant that the industrial lead was given to the US. I am very keen to avoid this type of thing in the future"

\section{David Dickson}

paign for genuine scientific activity.

Although throughout the Comecon block social doctrine states that science must serve the economy, in most states this is no more than a slogan; pure research continues following Brezhnev's dictum that "there is nothing more practical than a good theory". In Romania however, following President Ceauscescu's visit to China, a new trend began by which all institutes of pure research werc gradually turned into what Dr Dediu describes as "little more than factories".

Chemistry was the first to sufferthere is now no faculty of chemistry at all, only chemical engineering. The mathematics institute was destroyed in 1975 and some of the mathematicians were transferred to the Institute of Physics, some to industry. The Institute of Physics, in its turn. became the Institute of Physics and Instrument Production in autumn 1976. According to Dr Dediu, the Academy of Sciences no longer exists as a scientific forum. The whole emphasis is upon politics. Even Madame Elcana Ceauscescu, the wife of the leader, has been appointed an academician although she has no scientific training. 